\title{
ISOTHERM, KINETICS AND THERMODYNAMICS OF SYNTHETIC DYES ADSORPTION ONTO ACTIVATED CHARCOAL MADE FROM OIL PALM MIDRIB
}

\author{
M. Lutfi Firdaus ${ }^{1 *}$, Efa Susanti ${ }^{1}$, Ghufira ${ }^{2}$, Wiwit Alwi ${ }^{1}$ and Eko Swistoro ${ }^{1}$ \\ ${ }^{1}$ Graduate School of Science Education, University of Bengkulu, Bengkulu 38371, Indonesia \\ ${ }^{2}$ Department of Chemistry, University of Bengkulu, Bengkulu 38371, Indonesia \\ *E-mail: lutfi@unib.ac.id
}

\begin{abstract}
In this report, we prepared activated charcoal from oil palm midrib and used it as an adsorbent to decolorizeReactive Red and Direct Green as synthetic dyes in the sample solution. The response of various experiments conditions, such as contact time, solution $\mathrm{pH}$, temperature, the weight of adsorbent, and concentration of dyes, on adsorption of synthetic dyes, were evaluated along with the analysis of isotherms, kinetics, and thermodynamics adsorption parameters. At equilibrium, adsorption of dyes onto activated charcoal fitted well to Freundlich model giving coefficients of correlation $\mathrm{R}^{2} \geq 0.9$. At optimum conditions, capacities of adsorption for Reactive Red 120 and Direct Green 26 were 151 and $116 \mathrm{mg} / \mathrm{g}$, respectively. The kinetics study suggested that dyes adsorption onto activated charcoal followed the model of pseudo-second-order with thermodynamic parameters of $\Delta \mathrm{G}^{\circ}, \Delta \mathrm{H}^{\circ}$, and $\Delta \mathrm{S}^{\circ}$ were -0.21 to $-3.93 \mathrm{~kJ} / \mathrm{mol},-30.15$ to $-36.12 \mathrm{~kJ} / \mathrm{mol}$, and $0.003 \mathrm{~J} / \mathrm{mol} . \mathrm{K}$, respectively. Based on the experiments, we conclude that dyes adsorption was exothermic, spontaneous and an increase in the system entropy. The results of FT-IR analysis indicated the involvement of various functional groups, including hydroxyl and amine groups. This study emphasizes the potential of oil palm waste as an alternative low-cost adsorbent for the removal of dyes.
\end{abstract}

Keywords: Isotherm, kinetics, thermodynamics, activated charcoal, oil palm, synthetic dyes.

(C) RASĀYAN. All rights reserved

\section{INTRODUCTION}

Oil palm plantation and palm oil industry produce a large number of biomass wastes. In a typical palm oil industry, more than $60 \%$ of fresh fruit bunches and another form of biomass are turned into wastes, including mesocarp fibers, palm kernel shells, empty fruit bunches, as well as liquid effluent ${ }^{1-3}$. Most of the biomass wastes are either burnt in the open or disposed of in waste ponds. Therefore, palm oil industries contribute significantly to global warming by emitting carbon dioxide and methane gases ${ }^{4}$. Along with palm oil wastes problem, colored effluent from textile industries that used synthetic dyes often creates other environmental problems. Synthetic dyes, such as azo dye, are one of the most extensively used dyes for coloring clothes, textiles, and other goods. The discharge of dyes into the river system will produce intense color even in a small concentration of dyes that results in aesthetic and unpleasant sight. Moreover, dyes compound can be broken down to form aromatic amines that are hazardous and carcinogens ${ }^{5-6}$. As a consequent, it is crucial to remove dyes wastewater before their disposal to the river.

A widely used adsorbent of activated charcoal or activated carbon, usually derived from biomass, has small pores to increase the surface area for adsorption of interest compounds such as synthetic dyes. Physical or chemical activation is needed to produce activated carbon. In general, the chemicals preferred over physical activation due to the shorter time needed and lower temperatures for activating the raw materials $^{7-10}$.

This report describes the dyes adsorption onto activated carbon made from oil palm waste including its isotherms, kinetics, and thermodynamics adsorption parameters.

Rasayan J. Chem., 11(4), 1532-1536(2018)

http://dx.doi.org/10.31788/RJC.2018.1144030

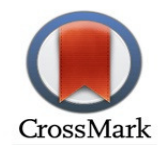


RASĀYAN J. Chem.

Vol. 11 | No. 4 |1532 - 1536| October - December | 2018

\section{EXPERIMENTAL}

\section{Material and Methods}

The waste of oil palm used in this research was leaf midrib.The oil palm midrib was collected from local oil palm plantation in Sumatera ${ }^{11}$. All solutions were prepared with distilled water. All reagents were purchased from Merck, pro-analysis grade. Dried oil palm midrib was carbonized at a temperature of $430^{\circ} \mathrm{C}$ for 30 minutes using a furnace. In order to achieve a similar particle size, the resulted charcoal was sieved by strainers 100 mesh. A $25 \% \mathrm{CaCl}_{2}$ was used for chemical activation by soaking the carbon into the solution for 24 hours. The activated charcoal was cleaned with distilled water and then dried using an oven for 30 minutes at $110^{\circ} \mathrm{C}$.

Thermostat shaker was used for batch adsorption experiments with a shaking of $150 \mathrm{rpm}$. Synthetic dyes stock solutions were made by dissolving weighed Reactive Red CI 120 (RR 120) and Direct Green CI 26 (DG 26)accurately in distilled water to give a concentration of $1,000 \mathrm{ppm}$. The working standards were prepared by dilution to achieve concentrations of 25, 50,75,100,125 and $150 \mathrm{ppm}$. An amount of $10 \mathrm{~mL}$ of dyes solution with an initial concentration of $15 \mathrm{ppm}$ and $0.10 \mathrm{~g}$ of the adsorbent was used. The system was kept at a designated temperature under shaking until equilibrium reached. The effect of $\mathrm{pH}$ on dyes decolorization was monitored by adjusting solutions $\mathrm{pH}(2-9)$ using $0.1 \mathrm{M} \mathrm{HCl}$ or $0.1 \mathrm{M} \mathrm{NaOH}$. The influence of exposure time on dyes decolorization was carried out from a short time to several hours. The sample was then taken, filtered and measured the absorbance with a UV-visible spectrophotometer (BioSpectrometer, Eppendorf) on the wavelength range of $400-700 \mathrm{~nm}^{7-8}$.

\section{Batch Adsorption Study}

\section{RESULTS AND DISCUSSION}

The FTIR spectra of oil palm midrib carbon and the corresponding activated charcoal were shown in Fig.-1. The broadband that lies in the range of $3700-3100 \mathrm{~cm}^{-1}$ is associated with the stretching of $-\mathrm{OH}$ group. The peak at $1629 \mathrm{~cm}^{-1}$ could be attributed with the $\mathrm{C}=\mathrm{C}$ stretching vibration. The peak observed at $1439 \mathrm{~cm}^{-1}$ is related to the bending -OH group. The peaks at the areas of $1200-900 \mathrm{~cm}^{-1}$ correspond to the $\mathrm{C}-\mathrm{O}$ stretching of dyes structures. Therefore, the formed activated charcoal has a structure with carbonyl hydrophilic and hydroxyl functional groups, that might be liable for the synthetic dye adsorption.

\section{Adsorption Isotherm}

Adsorption isotherm was conducted in this experiment to study the adsorption mechanism. Langmuir and Freundlich'sisothermswere selected for this research (Table-1). Langmuir isotherm theory is based on the assumption that adsorption is a chemical process as monolayer adsorption, which is written by the following equation ${ }^{12}$ :

$$
\frac{\mathrm{Ce}}{q_{e}}=\frac{1}{\mathrm{q}_{\max } \cdot \mathrm{K}_{\mathrm{L}}}+\frac{\mathrm{Ce}}{\mathrm{q}_{\max }}
$$

Where, Ce is a concentration of dye at equilibrium (ppm), qe is the amount of adsorbed dye at equilibrium $(\mathrm{mg} / \mathrm{g}), \mathrm{q}_{\max }$ is maximum adsorption capacity $(\mathrm{mg} / \mathrm{g})$, and $\mathrm{K}_{\mathrm{L}}$ is Langmuir constants $(\mathrm{L} / \mathrm{mg})$.

For the second adsorption model, Freundlich isotherm is an empirical equation employed to describe heterogeneous systems. Adsorbed dye amount, qe, is related to the dye concentration at equilibrium, Ce. The Freundlich equation is as follow ${ }^{13}$ :

$$
\log \mathrm{q}_{\mathrm{e}}=\log \mathrm{K}_{\mathrm{F}}+\frac{1}{\mathrm{n}} \log \mathrm{C}
$$

Where, $\mathrm{K}_{\mathrm{F}}$ is a constant, related to the bonding energy and $1 / \mathrm{n}$ is adsorption intensity that indicates the type of isotherm to be irreversible $(1 / \mathrm{n}=0)$, favorable $(0<1 / \mathrm{n}<1)$ and unfavorable $(1 / \mathrm{n}>1)$. Table 1 shows adsorptions of both RR 120 and DG 26 onto adsorbent were favorable with high adsorption capacity. At equilibrium, the results of coefficient of determination show that both dyes adsorption onto adsorbent tends to follow Freundlich isotherm model, with maximum adsorption capacities for RR 120 and DG 26 were 151 and $116 \mathrm{mg} / \mathrm{g}$, respectively. Based on these results, we concluded that the 
RASĀYAN J. Chem.

Vol. 11 | No. 4 |1532 - 1536| October - December | 2018

mechanism of dyes adsorption onto activated charcoal was a physisorption process through van der Walls forces or electrostatic attractions between the dyes and charcoal.

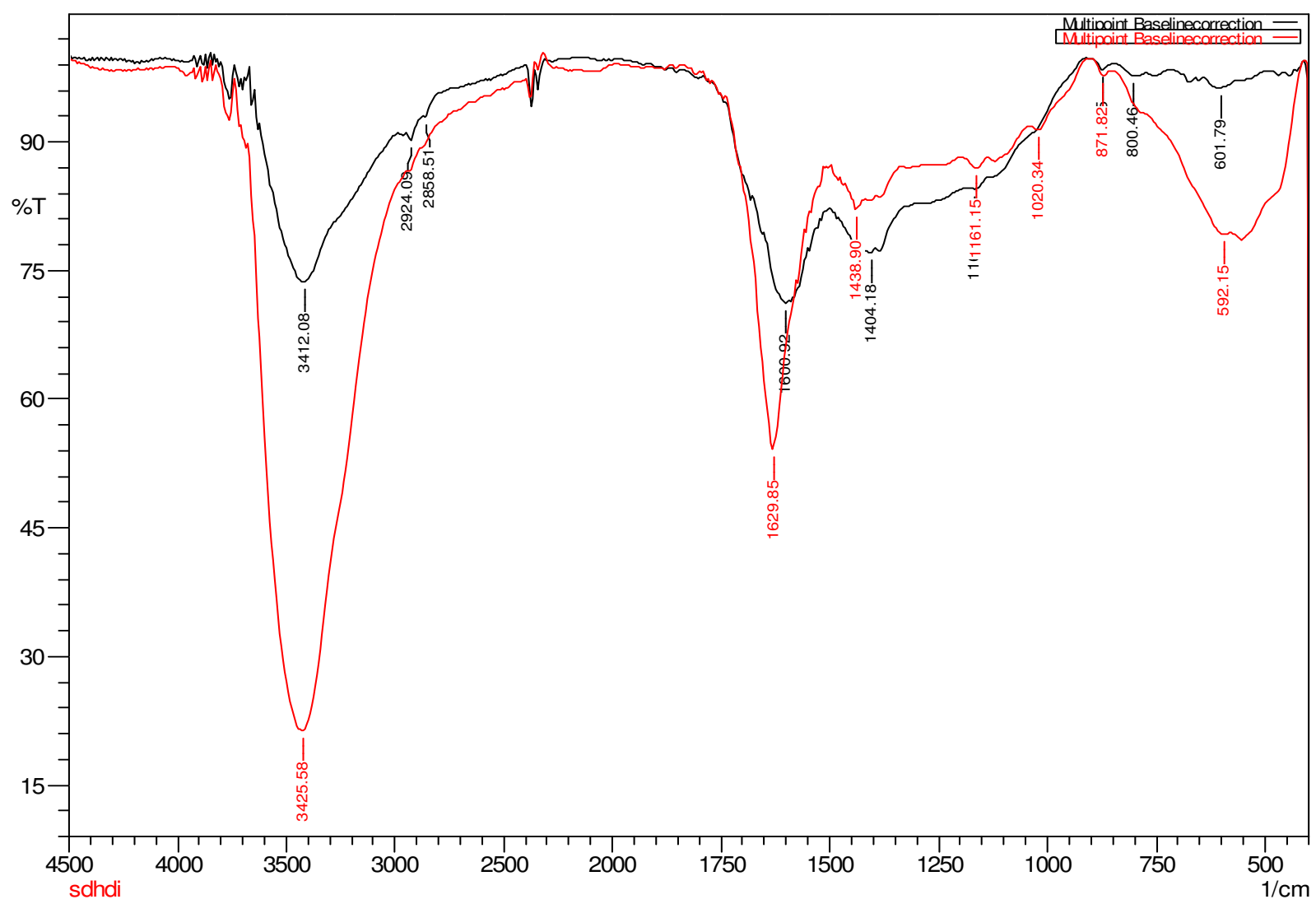

Fig.-1: FTIR Spectra of Carbon as An Adsorbent Before (Black Line) and After (Red Line) Chemical Activation by Using $25 \% \mathrm{CaCl}_{2}$.

Table-1: Isotherm Model Constants for RR 120 and DG 26 Adsorption onto Activated Charcoal

\begin{tabular}{l|c|c|c|c|c|c}
\hline \multirow{2}{*}{ Synthetic Dyes } & \multicolumn{3}{|c|}{ Langmuir Parameter } & \multicolumn{3}{c}{ Freundlich Parameter } \\
\cline { 2 - 7 } & $\mathrm{K}_{\mathrm{L}}$ & $\mathrm{q}_{\max }$ & $\mathrm{R}^{2}$ & $\mathrm{~K}_{\mathrm{F}}$ & $\mathrm{n}$ & $\mathrm{R}^{2}$ \\
\hline RR 120 & 0.003 & 151 & 0.6258 & 1.601 & 1.15 & 0.9987 \\
\hline DG 26 & 0.004 & 116 & 0.2318 & 1.303 & 1.17 & 0.8994 \\
\hline
\end{tabular}

\section{Adsorption Kinetics}

Two adsorption kinetics models, namely pseudo first order and pseudo-second-order, were used to examine the adsorption mechanism. The Lagergren rate expression for pseudo first order is expressed as $^{14}$ :

$$
\log (q e-q t)=\log q e-\frac{k_{1}}{2.303} t
$$

Where, $\mathrm{q}_{\mathrm{e}}(\mathrm{mg} / \mathrm{g})$ is the uptake equilibrium adsorption, $\mathrm{q}_{\mathrm{t}}(\mathrm{mg} / \mathrm{g})$ is the dye adsorbed on the charcoal at time $t$,and $k_{1}(1 / \mathrm{min})$ is the rate constant of the first order adsorption. The pseudo-second-order kinetic model in its integrated and linearized form is expressed as ${ }^{15}$ :

$$
\frac{\mathrm{t}}{\mathrm{q}_{\mathrm{t}}}=\frac{1}{\mathrm{k}_{2} \mathrm{q}_{\mathrm{e}}^{2}}+\frac{1}{\mathrm{q}_{\mathrm{e}}} \mathrm{t}
$$


RASĀYAN $J$. Chem.

Vol. 11 | No. 4 |1532 - 1536| October - December | 2018

Where, $\mathrm{k}_{2}$ is the second order adsorption rate constant $\left(\mathrm{q}_{\mathrm{e}}\right)$, and $\mathrm{k}_{2}$ were calculated from the slope and intercept of the plot of t/qt vs. t, respectively. Among the pseudo first order and pseudo-second-order models, which were tested to characterize the adsorption kinetically, the second one demonstrated the better fit of the empirical data with $\mathrm{R}^{2}$ from 0.98 to 0.99 (see Table-2 and Fig.-2).

\section{Adsorption Thermodynamics}

For the adsorption thermodynamic studies, the changes of free energy $\left(\Delta \mathrm{G}^{\circ}\right)$, entropy $\left(\Delta \mathrm{S}^{\circ}\right)$ and enthalpy $\left(\Delta \mathrm{H}^{\circ}\right)$ estimated from batch experiments that were accomplished at various temperatures and determined using the equations below:

$$
\begin{aligned}
& \Delta \mathrm{G}^{\circ}=-\mathrm{RT} \ln K \\
& \ln K=\frac{\Delta S^{\circ}}{R}-\frac{\Delta H^{\circ}}{R T}
\end{aligned}
$$

Table-2: Kinetic Parameters Estimated by the Pseudo First Order and Pseudo-Second Order Model for RR 120 and DG 26 Adsorption onto Activated Carbon

\begin{tabular}{c|c|c|c|c|c}
\hline \multirow{2}{*}{ Model } & \multirow{2}{*}{ Parameter } & \multicolumn{2}{|c|}{ RR 120 } & \multicolumn{2}{c}{ DG 26 } \\
\cline { 3 - 6 } & & $50(\mathrm{ppm})$ & $100(\mathrm{ppm})$ & $50(\mathrm{ppm})$ & $100(\mathrm{ppm})$ \\
\hline \multirow{3}{*}{ Pseudo first order } & $\mathrm{k}_{1}(1 / \mathrm{min})$ & 0.001 & 0.001 & 0.001 & 0.001 \\
\cline { 2 - 6 } & $\mathrm{q}_{\mathrm{e}}(\mathrm{mg} / \mathrm{g})$ & 11.49 & 23.68 & 11.37 & 23.77 \\
\cline { 2 - 6 } & $\mathrm{R}^{2}$ & 0.69 & 0.80 & 0.89 & 0.77 \\
\hline \multirow{3}{*}{ Pseudo second order } & $\mathrm{k}_{2}(1 / \mathrm{min})$ & 0.113 & 0.034 & 0.078 & 0.049 \\
\cline { 2 - 6 } & $\mathrm{q}_{\mathrm{e}}(\mathrm{mg} / \mathrm{g})$ & 1.24 & 2.05 & 1.46 & 1.75 \\
\cline { 2 - 6 } & $\mathrm{R}^{2}$ & 0.99 & 0.99 & 0.98 & 0.99 \\
\hline
\end{tabular}
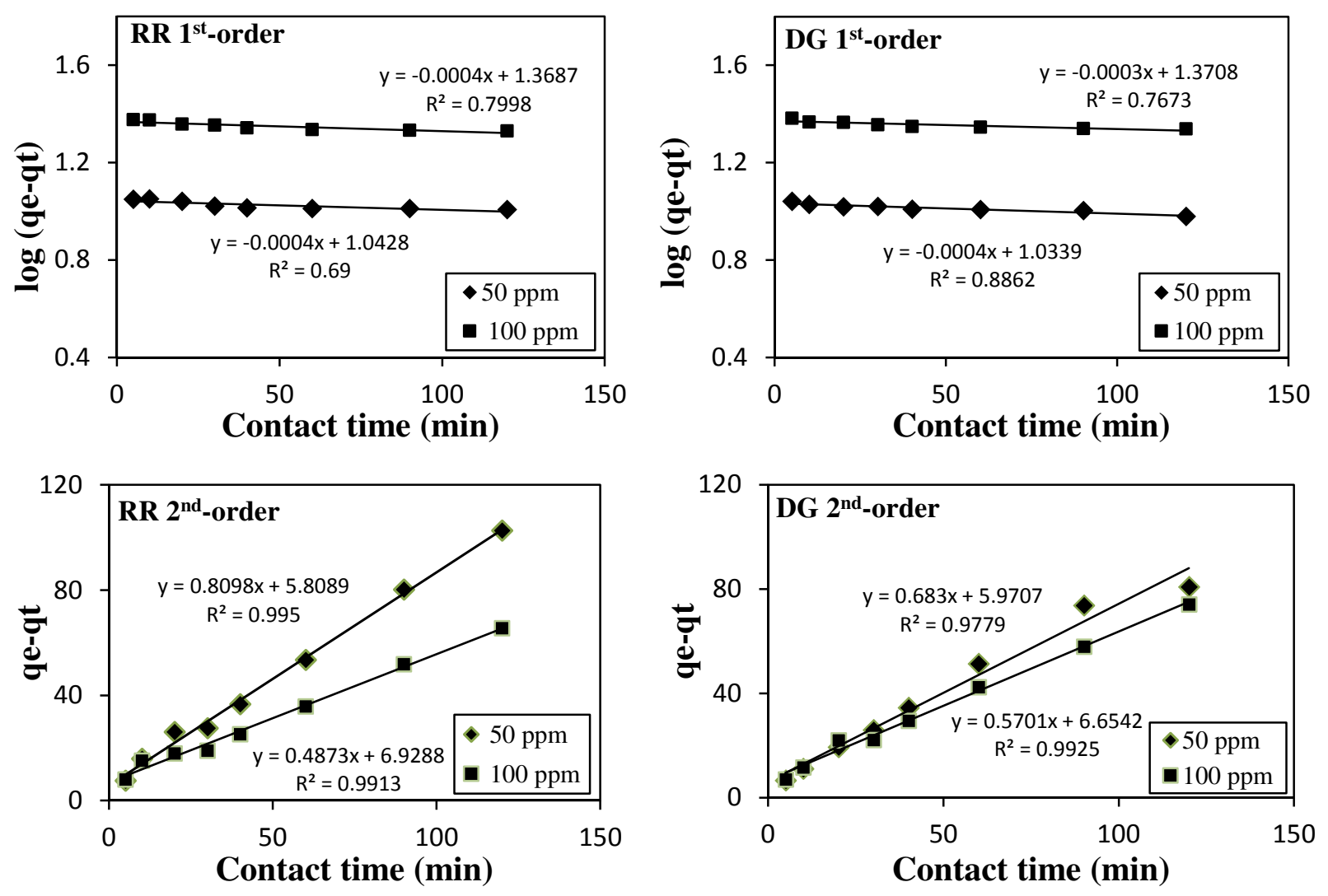

Fig.-2: Pseudo First Order and Pseudo Second Order Plot at Two Different Initial Synthetic Dyes Concentration. RR 120 Dyes on the Left Panel and DG 26 Dyes on the Right Panel. 
The results of these parameters are compiled in Table-3. The negative change of free energy $\left(\Delta \mathrm{G}^{\circ}\right)$ values for RR and DG govern the spontaneous process. The positive rates of entropy change $\left(\Delta \mathrm{S}^{\circ}\right)$ for both dyes affirms the elevated randomness at the solid and solution interface along the adsorption of the synthetic dyes on the active sites of the activated charcoal. The change of enthalpy $\left(\Delta \mathrm{H}^{\circ}\right)$ for both dyes were negative or exothermic as the reduction in adsorption with successive increases in temperature.

Table-3: Thermodynamic Parameters Estimated for RR 120 and DG 26 Adsorption onto Charcoal

\begin{tabular}{c|c|c|c|c|c}
\hline \multirow{2}{*}{ Synthetic Dyes } & \multicolumn{3}{|c|}{$-\Delta \mathrm{G}^{\circ}(\mathrm{kJ} / \mathrm{mol})$} & \multirow{2}{*}{$-\Delta \mathrm{H}^{\circ}(\mathrm{kJ} / \mathrm{mol})$} & \multirow{2}{*}{$\Delta \mathrm{S}^{\circ}(\mathrm{J} / \mathrm{mol} . \mathrm{K})$} \\
\cline { 2 - 4 } & $303 \mathrm{~K}$ & $313 \mathrm{~K}$ & $323 \mathrm{~K}$ & & \\
\hline RR 120 & 3.93 & 2.35 & 1.86 & 36.12 & 0.003 \\
\hline DG 26 & 1.67 & 1.25 & 0.21 & 30.15 & 0.003 \\
\hline
\end{tabular}

\section{CONCLUSION}

Development of activated charcoal made from oil palm midrib is reported in this paper to decolorize hazardous dyes in textile industry wastewater. The method is environmentally friendly as a result of the use of agricultural waste to remove textile wastewater. Based on the experimental data, we conclude that the mechanism of dyes adsorption onto activated charcoal was achieved by van der Walls forces and electrostatic attractions between the dyes and activated charcoal. On the optimized experimental condition, adsorption capacities of activated charcoal to remove Reactive Red and Direct Green dyes were 151 and $116 \mathrm{mg} / \mathrm{g}$, respectively. Our results suggest that the use of low-cost oil palm waste as the adsorbent is effective to remove synthetic dyes from textile wastewaters, and therefore could be used as an alternative to the expensive methods currently employed.

\section{ACKNOWLEDGMENT}

We gratefully acknowledge the financial support provided by the Indonesian Ministry of Research, Technology and Higher Education. We acknowledge anonymous reviewers for the constructive comments that significantly improved the first paper.

\section{REFERENCES}

1. Y.A.B. Neolaka, E.B.S. Kalla, G.A. Malelak, N.K. Rukman, G. Supriyanto and N.T. Puspaningsih, Rasayan J. Chem., 11(2), 494 (2018), DOI: 10.31788/RJC.2018.1121994

2. W.P.Q. Ng, H.L. Lam, F.Y. Ng, M. Kamal and J.H.E. Lim, Journal of Cleaner Production, 34, 57 (2012), DOI: 10.1016/j.jclepro.2012.04.004

3. Y.A.B. Neolaka, E.B.S. Kalla, G. Supriyanto, Suyanto, N. N. T. Puspaningsih, Rasayan J. Chem., 10(2), 606 (2017), DOI: 10.7324/RJC.2017.1021710

4. Rahmi and Lelifajri, Rasayan J. Chem., 10(2), 634 (2017), DOI: 10.7324/RJC.2017.1021736

5. S.A. Yahya and M.I. El-Barghouthi, Dyes Pigments, 77, 16 (2008), DOI: 10.1016/j.dyepig.2007.03.001

6. Y. Li, Q. Du, T. Liu, X. Peng, J. Wang, J. Sun, Y. Wang, S. Wu, Z. Wang, Y. Xia and L. Xia, Chemical Engineering Research and Design, 91, 361 (2013), DOI: 10.1016/j.cherd.2012.07.007

7. M.L. Firdaus, N. Krisnanto, W. Alwi, R. Muhammad and M.A. Serunting, Aceh International Journal of Science and Technology, 6, 1 (2017), DOI: 10.13170/aijst.6.1.5502

8. M.L. Firdaus, M. Puspita, W. Alwi, Ghufira, Nurhamidah and R. Elvia, AIP Conference Proceedings, 1904, 020066(2017), DOI: 10.1063/1.5011923

9. R.A. Sari, M.L. Firdaus and R. Elvia, Alotrop, 1, 10 (2017)

10. B. Sivakumar, P. Nithya, S. Karthikeyan and C. Kannan, Rasayan J. Chem.,7, 161 (2014)

11. S. Astuti, R. Yahya and A. Sundaryono, PENDIPA Journal of Science Education, 2, 69 (2018)

12. I. Langmuir, J. Am. Chem. Soc., 40, 1361 (1918)

13. H. Freundlich, Z. Phys. Chem., 57, 385 (1907)

14. Y. S. Ho, G. McKay, Water Res., 33, 578 (1999), DOI: 10.1016/S0043-1354(98)00207-3

15. G. McKay, Y.S. Ho, Process Biochem., 34, 451 (1999), DOI: 10.1016/S0032-9592(98)00112-5

[RJC-4030/2018] 